\title{
Functional state of the udder of cows after the treatment of the udder nipples with hygiene products during milking
}

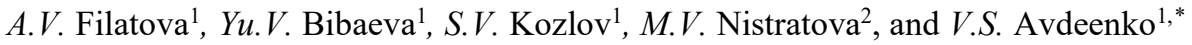 \\ ${ }^{1}$ Saratov State Agrarian University named after N.I. Vavilov": Teatralnaya Ploshchad, 1, 410012, \\ Saratov, Russia \\ ${ }^{2}$ Volgograd State Agrarian University: 29 Universitetskaya Str., 400094, Volgograd, Russia
}

\begin{abstract}
During the experiments, it was found that the latent period of the breast-feeding reflex is $22.8 \%$ less, the milking time is $10.8 \%$ less. The average milking intensity increases by $22.7 \%$, intravenous pressure - by $19.4 \%$, with an increase in single milk yield by $15.3 \%$. The concentration of Staph. aigees, Strep. agalactiae, was lower when the nipples were immersed in a solution of hygiene products "Chlorhexidine bigluconatealoe" and "Teasfoam Supercow-olive oil" before and after milking, compared with untreated nipples. Controlled treatment of the udder nipples and mammary gland with the hygienic product "HGB aloe" before and after cow milking with high milk yields in $2.4 \%$ of animals prevents hyperkeratosis of the udder nipples and in $12.1 \%$ subclinical mastitis, against $5.4 \%$ heperkeratosis and $26.5 \%$ subclinical mastitis of control groups of dairy cows. Using hygienic products, an increase in milk yield in cows is provided by $18.45 \ldots .22 .0 \%$, and the functioning of the udder by $16.45 \ldots 26.34 \%$. To improve the functioning of the udder during lactation in cows, hygiene products "Chlorhexidine bigluconate-aloe" or "Teasfoam Supercow-olive oil" should be used to treat the udder nipples before and after each milking.
\end{abstract}

\section{Introduction}

In recent years, milk producers have been paying great attention to maintaining high milk productivity in cows, preventing diseases and premature culling of highly productive cows, using various innovative technologies $[1,11]$. Animal breeding based on the principle of productivity and the use of new innovative technologies in feeding and keeping highyielding animals, unfortunately, leads to a weakening of the adaptive potential to changing environmental conditions, the removal of the factor of individual treatment of service personnel with animals, increased sensitivity to the constantly increasing anthropogenic load, $[2,4]$. Thus, among the producers of whole milk who use in their practice various innovative methods to increase milk yield and preserve the good functioning of the udder, there is a main reason why the quality of milk decreases $[5,9]$, these is infection of the

\footnotetext{
*Corresponding author: avdeenko8686@mail.ru
} 
udder nipples with hyperkeratosis and mammary gland - with subclinical mastitis. One of the causes of hyperkeratosis and subclinical mastitis $[6,7]$ is the lack of conditions for ensuring hygiene of the udder nipples during milking and preventing the penetration of microorganisms and foreign objects galactogenically into the mammary gland, since the nipple canal remains open for about 30 minutes after milking. Colonization of the nipple skin with $S$. aureus increases the risk of intramammary infection $[8,10]$. At the same time, the number of bacteria on the nipples before cluster application may be affected by the procedure for preparing the nipples before milking. Thus, $[3,12]$ it is proved that disinfection of the udder nipples during milking reduces the number of bacteria on the nipple skin, before and after milking, compared with untreated nipples. The use of such innovative technologies in the practice of dairy cattle breeding makes it possible to enhance the effect of pre-milking preparation of the breast for milking, thereby activating the alveolar structures of the mammary gland and, as a result, increasing the longevity of a productive animal.

Purpose of research. To study the effect of treatment of udder nipples before and after milking cows with hygiene products "Chlorhexidine bigluconate-aloe" and "Teasfoam Supercow-olive oil" on milk productivity and the functional state of the mammary gland during lactation of dairy cattle.

\section{Material and research methods}

Experimental studies were conducted on 3,450 cows with a productivity of more than $8 \ldots 10$ tons of milk. The methodology of the work consisted of accounting for the milk yield of cows for 305 days of lactation, conducting a medical examination of the milking herd. Clinical and gynecological studies of breeding stock and laboratory diagnostics of milk for the qualitative composition and incidence of subclinical mastitis were carried out. To determine the preventive effectiveness of the use of hygiene products in the process of milking cows, they were divided into identical experimental groups. The first experimental group, the second experimental group (1,150 cows). There were also the third and fourth experimental groups (control), 575 dairy cows each, disinfection of the udder nipples was not carried out. The nipples and udders of animals (1,150 cows) from the 1 st experimental group (dairy herd A) were treated with the hygiene product "Teasfoam Supercow-olive oil", in the animals of the 2nd experimental group - the control group (dairy herd B, 575 cows) udder nipples were not treated with during milking. Udder nipples and mammary gland of animals (1,150 cows) from the 3 experimental group (dairy herd V) were treated with the hygienic product "Chlorhexidine bigluconate-aloe", in the animals of the 4 experimental group - the control (dairy herd F, 575 cows) udder nipples were not treated with during milking. This procedure was performed before and after milking. In animals, when hyperkeratosis of the udder nipples and subclinical mastitis or other diseases were diagnosed during the experiment, they were excluded from the experiment and their indicators were not used in general statistics. The data analysis was carried out using the standard computer program Microsoft Excel 2013 SPSS 10.0.5 for Windows "Statistics", adapted for the PC "Pentium - 10".

\section{Results and discussion}

The experiments conducted show that the use of hygiene products "Chlorhexidine bigluconate-aloe" and "Teasfoam Supercow-olive oil" for the treatment of udder nipples before and after milking increases milk yield for 305 days of lactation (Table 1). 
Table 1. Milk productivity of cows treated with hygienic products

\begin{tabular}{|l|c|c|}
\hline \multirow{2}{*}{ Groups of cows } & \multicolumn{2}{|c|}{ Indicators } \\
\cline { 2 - 3 } & $\begin{array}{c}\text { milk yield for 305 days } \\
\text { of lactation, kg }\end{array}$ & $\begin{array}{c}\text { Average milk yield per } \\
\text { day, } \mathrm{kg}\end{array}$ \\
\hline 1. experiment (dairy herd A) & $8986 \pm 12.56^{*}$ & $40.8 \pm 0.2^{*}$ \\
\hline 2. control (dairy herd B) & $8270 \pm 13.45$ & $38.7 \pm 0.2$ \\
\hline 3. experiment (dairy herd V) & $10654 \pm 10.65^{*}$ & $56.7 \pm 0.2^{*}$ \\
\hline 4. control (dairy herd F) & $10128 \pm 11.76$ & $53.6 \pm 0.4$ \\
\hline
\end{tabular}

Note: hereafter $* p<0.05 ; * * p$

After everyday treatment during 14 days with hygiene products "Teasfoam Supercow-olive oil" the average daily milk yield of cows was $40.8 \pm 0,2 \mathrm{~kg}, p<0,05$ (dairy herd A), against $38,7 \pm 0.2 \mathrm{~kg}$ in the control group (dairy herd B), and the use of hygiene products, "Chlorhexidin digluconate-aloe" was $56.7 \pm 0,2 \mathrm{~kg}, p<0,05$ (dairy herd V), vs $53.6 \pm 0.4 \mathrm{~kg}$ in the control group of cows (dairy herd F). In experimental cows, there was a significant decrease in the value of the galvanic skin reaction (GSR) by $12.8 \%$ after treatment of the udder nipples and mammary gland with hygiene products "Chlorhexidine bigluconate-aloe" and "Teasfoam Supercow-olive oil" (dairy herd V and A). During the research and production experience, it was found that as a result of the treatment of the udder nipples and mammary gland with the use of hygiene products "Chlorhexidine bigluconate-aloe" and "Teasfoam Supercow-olive oil", the average daily milk productivity of cows (dairy herd A and V), compared with the control groups (dairy herd B and F), which did not use hygiene products during milking, increased by $6.1 \%$. If to consider that the decrease in milk yield by $5.7 \%$ in the control groups (dairy herd $\mathrm{B}$ and $\mathrm{F}$ ), then the increase in average productivity in the experimental groups (dairy herd A and V) increased by $11.8 \%$. Consequently, the use of hygiene products "Chlorhexidine bigluconate-aloe" and "Teasfoam Supercow-olive oil "(dairy herd A and V) during lactation increases milk yield in cows by $6 . . .9 \%$, Table 2 .

Table 2. Milk yield for lactation of cows, fat and protein content in milk after the use of hygiene products before and after milking.

\begin{tabular}{|l|c|c|c|}
\hline \multicolumn{1}{|c|}{ Indicators } & $\begin{array}{c}\text { Milk yield for } \\
\text { lactation, } \mathrm{kg}\end{array}$ & Fat content, $\%$ & Protein content, $\%$ \\
\hline 1. experiment (dairy herd A) & $8986 \pm 12.56^{*}$ & $3.36 \pm 0.04$ & $3.35 \pm 0.08^{*}$ \\
\hline 2. control (dairy herd B) & $8270 \pm 13.45$ & $3.29 \pm 0.07$ & $3.23 \pm 0.04$ \\
\hline 3. experiment (dairy herd V) & $10654 \pm 10.65^{*}$ & $3.32 \pm 0.06$ & $3.24 \pm 0.05$ \\
\hline 4. control (dairy herd F) & $10128 \pm 11.76$ & $3.28 \pm 0.06$ & $3.23 \pm 0.09$ \\
\hline
\end{tabular}

As a result of the application of the procedure of pre-milking treatment of the udder nipples and mammary gland with hygiene products "Chlorhexidine bigluconate-aloe" and "Teasfoam Supercow-olive oil", the latent period of the milk transfer reflex was reduced in the experimental groups of cows (dairy herd A and V) in relation to the control (dairy herd $\mathrm{B}$ and F) animals by $8.5 \%$, the milk yield per 1 minute of milking in experimental cows of dairy herd $\mathrm{A}$ and $\mathrm{V}$ increased by $5.1 \%$, while in cows of dairy herds $\mathrm{B}$ and $\mathrm{F}$ remained almost at the same level, Table 3.

Table 3. Average milking intensity before and after application of hygiene products, $\mathrm{g} / \mathrm{min}$.

\begin{tabular}{|c|c|c|c|c|}
\hline \multirow{2}{*}{ Studied object } & \multicolumn{2}{|c|}{ Dairy herd A and B } & \multicolumn{2}{c|}{ Dairy herd V and F } \\
\cline { 2 - 5 } & $\begin{array}{c}\text { Before } \\
\text { application }\end{array}$ & $\begin{array}{c}\text { After } \\
\text { application }\end{array}$ & $\begin{array}{c}\text { Before } \\
\text { application }\end{array}$ & $\begin{array}{c}\text { After } \\
\text { application }\end{array}$ \\
\hline $\begin{array}{c}\text { Foreudders } \\
\text { Posterior udders }\end{array}$ & $239.6 \pm 13.1$ & $230.4 \pm 11.3$ & $331.8 \pm 10.0$ & $293.0 \pm 12.0^{*}$ \\
& $249.9 \pm 10.6$ & $239.8 \pm 11.2$ & $338.6 \pm 11.0$ & $299.2 \pm 12.1^{*}$ \\
\hline
\end{tabular}




\begin{tabular}{|c|c|c|c|c|}
\hline Difference & 10.43 & 10.41 & 10.21 & 10.21 \\
\hline
\end{tabular}

The duration of milking in cows of dairy herds $\mathrm{A}$ and $\mathrm{V}$ decreased by an average of $6.7 \%$, and in cows of dairy herds B and F by an average of 5.4\%. Analysis of the average statistical data showed that the milk yield in cows after 14 days of treatment of the udder nipples and mammary glands with hygienic means is $245 \mathrm{~kg}(p<0.01)$ higher than in dairy herds $\mathrm{A}$ and $\mathrm{V}$ and the milk yield per day of these animals averaged $48.8 \mathrm{~kg}$, and dairy herd $\mathrm{B}$ and $\mathrm{F}$ an average of $37.8 \mathrm{~kg}$. The completeness of milking, as a result of additional premilking stimulation by rubbing the gel of a hygiene product into the skin of the udder nipples and milk lobes, increased in both experimental groups, and an increase in milk productivity was noted in cows of dairy herds $\mathrm{A}$ and $\mathrm{V}$ from 1 to 4 days, after the start of treatment of the udder nipples and mammary gland with hygiene products. On average, during the period of treated udder nipples and mammary gland with hygiene products after such additional stimulation, the amount of milk per average milk yield per day in cows increased by $6.5 \%$. After 14-day treatment of the udder nipples and mammary gland with hygiene products "Chlorhexidine bigluconate-aloe" and "Teasfoam Supercow-olive oil", an increase in milk yield was observed on average per day in cows of dairy herds A and V. Thus, the increase in cows of dairy herd A was $5.9 \%$, in cows of dairy herd B $-2.7 \%$. According to the control milkings, the milk yield coefficient increased from 642 to $668 \mathrm{~kg}$ in cows of dairy herd A and V, and in cows of dairy herd B and F from 591 to $611 \mathrm{~kg}$ and remained almost at the same level. The latent period of the milk-giving reflex in cows of dairy herd $\mathrm{A}$ and $\mathrm{V}$ practically did not change (55...61 seconds), while in cows of dairy herd $\mathrm{B}$ and $\mathrm{F}$ it decreased by $13.3 \%$, Table 4 .

Table 4. The effect of the treatment of the udder nipples of the mammary gland with hygiene products on the milk-giving reflex in cows

\begin{tabular}{|l|c|c|c|c|}
\hline \multirow{2}{*}{ Indicator } & \multicolumn{4}{|c|}{ Experiment } \\
\cline { 2 - 5 } & \multicolumn{2}{|c|}{ Dairy herd A and V } & \multicolumn{2}{c|}{ Dairy herd B and F } \\
\cline { 2 - 5 } & background & 14 days & background & 14 days \\
\hline $\begin{array}{l}\text { Intravenous pressure, } \\
\mathrm{g} / \mathrm{cm}^{3}\end{array}$ & $4.75 \pm 0.10$ & $5.67 \pm 0.13^{*}$ & $4.97 \pm 0.07$ & $5.02 \pm 0.09$ \\
\hline $\begin{array}{l}\text { Latent period of the } \\
\text { breast-feeding reflex, sec. }\end{array}$ & $33.2 \pm 0.93$ & $25.7 \pm 0.89^{*}$ & $32.7 \pm 1.9$ & $32.3 \pm 1.3$ \\
\hline
\end{tabular}

Intravenous pressure during pre-milking preparation of the udder on the 14th...17th day of the use of hygiene products for the treatment of the udder nipples and mammary gland and the reaction to pre-milking preparation was higher in cows of the dairy herd $\mathrm{A}$ and $\mathrm{V}$ by $13.0 \%,(p<0,05)$, whan in cows of dairy herd $\mathrm{B}$ and $\mathrm{F}$ it was $5.9 \%$. The analysis of the data presented in Table 4 showed that the milk-giving reflex when using hygiene products before and after milking cows in dairy herds $\mathrm{A}$ and $\mathrm{V}$ is more intense, so the latent period of the milk-giving reflex was $12.8 \%$ less, and the milking time was $10.8 \%$ less. While the average milking intensity was $12.7 \%$ higher, the intravenous pressure was $9.4 \%$ higher, and the milk yield per day increased by $5.3 \%$. Analyses of control milkings carried out 14 days after the use of hygiene products showed that after applying the gel of the hygiene product "Chlorhexidine bigluconate-aloe" to the nipples and udder skin, the bacterial contamination decreased to $3.59 \pm 0.475$ thousand bacteria per $\mathrm{cm}^{2}$, the decrease occurred by 9 times, Table 5. 
Table 5. Microbial contamination before and after the use of hygiene products

\begin{tabular}{|l|c|c|c|}
\hline \multirow{2}{*}{ Group } & \multirow{2}{*}{$\begin{array}{c}\text { Number of } \\
\text { samples }\end{array}$} & $\begin{array}{c}\text { of milk } \\
\left(10^{3} \mathrm{~m} . \mathrm{cl} . / \mathrm{ml}\right)\end{array}$ & $\begin{array}{c}\text { of nipple skin } \\
\left(10^{3} \mathrm{~m} . \mathrm{cl}^{\prime} / \mathrm{cm}^{2}\right)\end{array}$ \\
\hline $\begin{array}{l}\text { "Chlorhexidine bigluconate-aloe" } \\
\text { (dairy herd V) }\end{array}$ & 20 & $129.62 \pm 0.033^{* *}$ & $31.49 \pm 0.045^{* *}$ \\
\hline $\begin{array}{l}\text { "Teosfoam Supercow-olive oil" (dairy } \\
\text { herd A) }\end{array}$ & 20 & $146.18 \pm 0.068^{* *}$ & $35.67 \pm 0.077^{*}$ \\
\hline $\begin{array}{l}\text { Udder nipples were not treated (dairy } \\
\text { herd B and F) }\end{array}$ & 20 & $217.2 \pm 0.044$ & $39.87 \pm 0.025$ \\
\hline
\end{tabular}

After the use of the studied hygiene products, the incidence of subclinical mastitis decreased in animals after 15 days of their use. The incidence rate decreased by 1.67 times (Fig. 1).

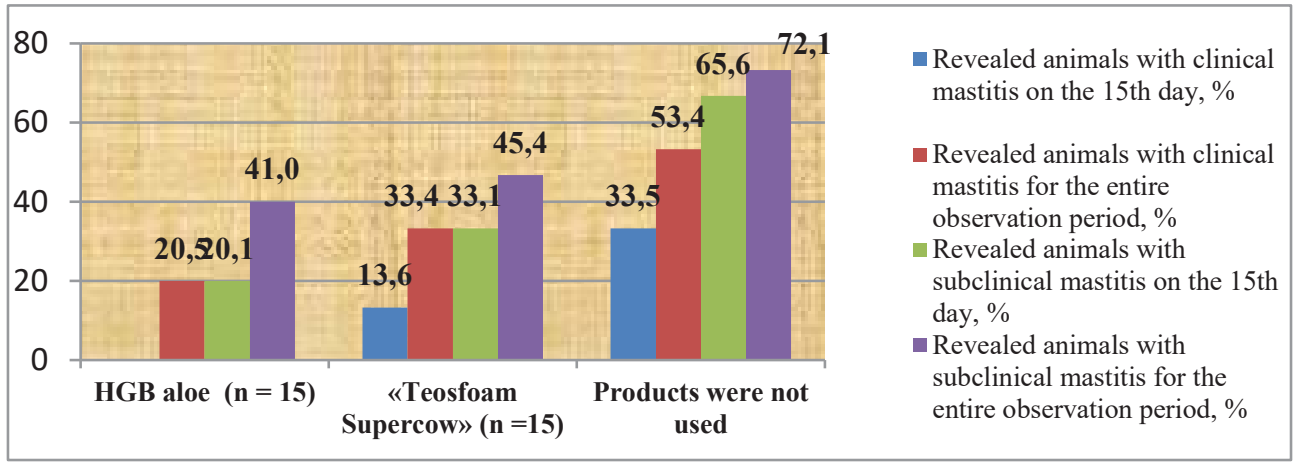

Fig. 1. Graphic representation of the preventive effectiveness of udder diseases in cows using hygiene products.

After the completion of lactation from the 3rd experimental group, dairy herd $\mathrm{V}$, (controlled disinfection of the udder nipples with a hygienic agent "HGB aloe" before and after milking), hyperkeratosis was detected in $2.53 \%$ of animals, subclinical mastitis was diagnosed in $11.91 \%$ of animals (Fig. 2).

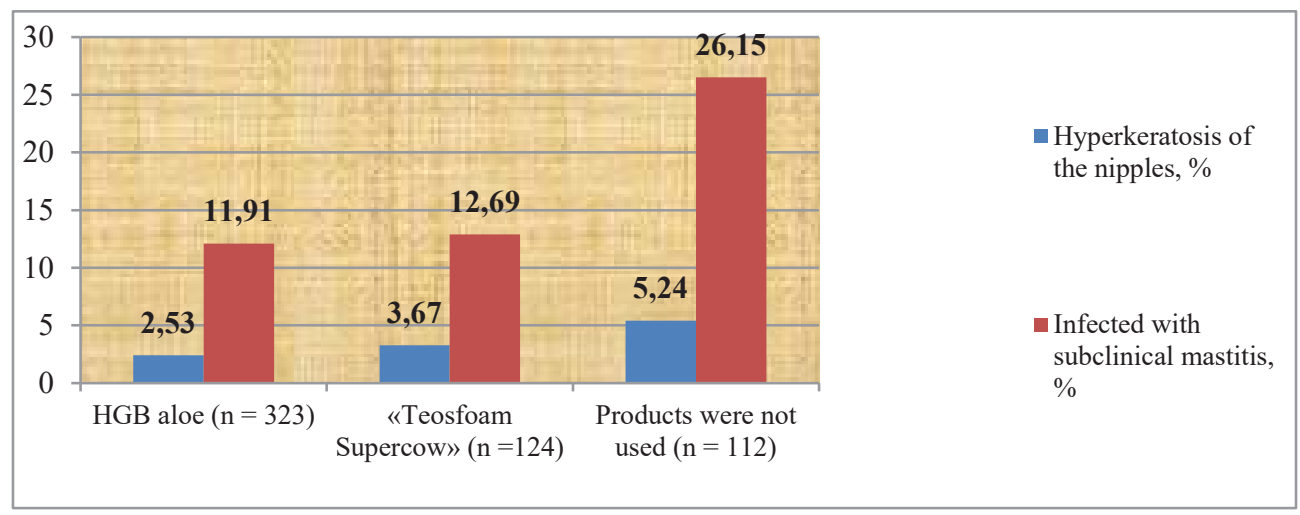

Fig. 2. Graphic representation of the preventive effectiveness of diseases of the udder nipples with hyperkeratosis and breast with subclinical mastitis with the use of hygiene products.

In animals from the 1st experimental group, dairy herd A, (controlled disinfection of the udder nipples with "Teasfoam Supercow-olive oil"), hyperkeratosis of the udder nipples was found here in $3.67 \%$ of cows and in $12.69 \%$ of subclinical mastitis. Udder nipples and mammary glands were not treated in animals from the control groups, dairy 
herds $\mathrm{B}$ and $\mathrm{F}$. The results were as follows: hyperkeratosis of the udder nipples was diagnosed in $5.24 \%$ of cows. $26.15 \%$ of the animals fell ill with subclinical mastitis. As shown by the results of studies of milk obtained from dairy cows, which used hygienic means before and after milking, the content of somatic cells in $1 \mathrm{ml}$ was $163.3 \pm 17.4$ thousand, $p<0.01$ (dairy herd V) when treating nipples with hygiene product "Chlorhexidine bigluconate-aloe "(Fig. 3).

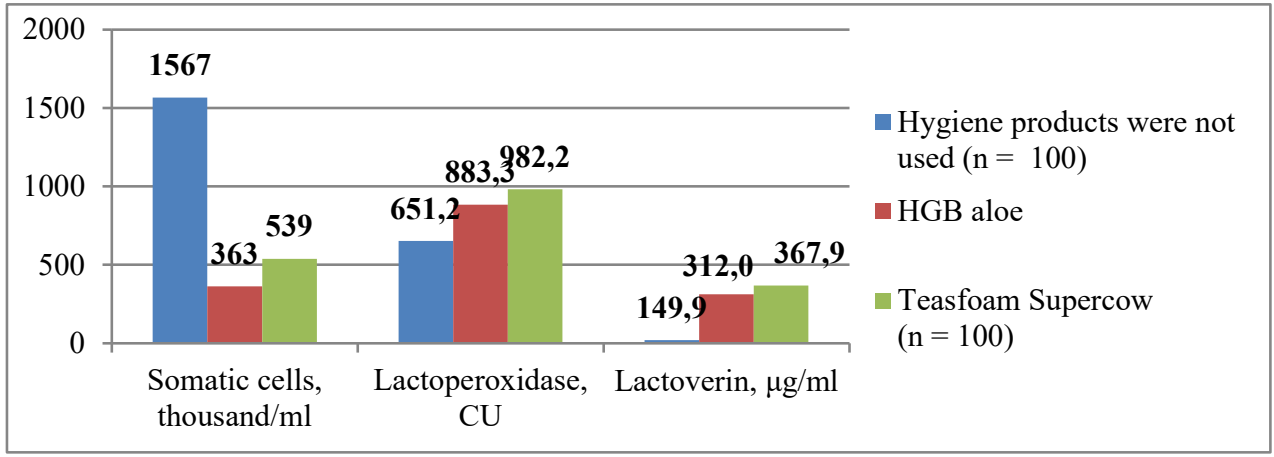

Fig. 3. Graphic representation of the level of somatic cells, lactoferin and lactoperoxidase in cow's milk after the use of hygiene products before and after milking.

When using the hygiene product "Teosfoam Supercow-olive oil" (dairy herd A) in cows, the level of somatic cells was $399.1 \pm 13.7$ thousand $/ \mathrm{ml},(p<0.05)$, against $570.2 \pm 15.7$ thousand $/ \mathrm{ml}$, when hygiene products were not used during milking, dairy herds B and $\mathrm{F}$. When the udder nipples and mammary gland were treated with "Chlorhexidine bigluconatealoe" before and after milking, dairy herd V, the activity of lactoperoxidase increased by $26.35 \%$, and the activity of lactoferin was 2.15 times lower compared to the content in animals that did not use hygiene products before and after milking, dairy herd F.

\section{Conclusions}

An increase in milk yield in cows and an improvement in the functional state of the udder after the use of hygiene products "Chlorhexidine bigluconate-aloe" and "Teosfoam Supercow-olive oil" were found. The milk-giving reflex when treating the udder nipples and mammary gland with hygienic means is more intense, since its latent period decreased by $12.8 \%$, the milking time by $10.8 \%$, and the milking intensity increased by $12.7 \%$ on average per day, intravenous pressure by $9.4 \%$, and the total milk yield per day increased by $5.3 \%$. The concentration of Staph. aigees, Strep. agalactiae, was lower when the nipples were immersed in a solution of hygiene products "Chlorhexidine bigluconate-aloe" and "Teasfoam Supercow-olive oil" before and after milking, compared with untreated nipples. Controlled treatment of the udder nipples and mammary gland with the hygienic product "HGB aloe" before and after cow milking with high milk yields in $2.4 \%$ of animals prevents hyperkeratosis of the udder nipples and in $12.1 \%$ subclinical mastitis, against $5.4 \%$ and $26.5 \%$ of control groups of dairy cows.

\section{References}

1. V.S. Avdeenko, N.V. Rodin, A. V. Avdeenko, D. Abdassemed, Agrarian Scientific Journal, - Saratov State Agrarian University named after N.I. Vavilov, 10, 27-29 (2013) 
2. A.S. Barkova, A.F. Kolchina, M.I. Barashkin, E.I. Shurmanova, Agrarian Bulletin of the Urals, 10 (116), 18-21 (2013)

3. Annabelle Beaver, Rebecca K. Meagher, Marina A. G. von Keyserlingk, Daniel M. Weary, Journal of Dairy Science, 102(7), 5784-5810 (2019)

4. C. Baumberger, J.F. Guarín, P.L. Ruegg, J Dairy Sci., 99, 2915-2929 (2016) doi: 10

5. B.D. Enger, R.R. White, S.C. Nickerson, L.K. Fox, J Dairy Sci., 99, 9900-9011 (2016) doi: 10 .

6. D. Gleeson, B. O'Brien, EAAP. Warsaw: 66th Annual Meeting; Effectiveness of teat disinfection formulations containing polymeric biguanide compounds, 281-231 (2015)

7. F. Gome, M. Henriques, Curr. Microbiol 72(4), 377-382 (2016) doi:10

8. H. Fjeld, E. Lingaas, Polyhexanide - Safety and efficacy as an antiseptic. Tidsskrift for den Norske laegeforening 136(8), 707-711 (2016)

9. A.C. Izquerdo, JEG. Liera, R.E., Cervantes, EAV Castro et al. Production of Milk and Bovine Mastitis. J. Adv. Dairy Res. S 174/ doi: 10. (2017)

10. B-M. Kahar, et al., J Hosp Infect. 90(3), 248-252 (2015) doi: 10

11. A. Kramer, Th. Eberlein, G. Müller, J. Dissemond, O. Assadian, Journal of Wound Care 28(4) (2019) https: //doi.org /10.12968/ jowc. 28.4.246.

12. J.M. Morton, J.F. Penry, J. Malmo, G.A. Mein, Premilking teat disinfection: is it worthwhile in pasture-grazed dairy herds. J Dairy Sci, 97, 7525-7537 (2014) 